Japanese Research in Business History 2009 | 26

\title{
Unsuccessful Entry of Foreign Multinationals in Japan: General Foods Corporation in the Economic Miracle Days
}

\author{
Tetsuya KUWAHARA \\ Fukuyama University
}

\section{INTRODUCTION}

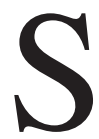

INCE the nineteenth century, multinational corporations have played a central role in the development of the world economy, acting as the engines of economic development around the globe. In Japan's modern economic development too, multinational corporations have played a critical role as catalyst for the creation and development of industry. ${ }^{1}$ In 1930, of the world's 500 largest industrial companies by assets, excluding 23 Japanese companies, 29 of the 477 foreign companies invested directly in Japan, this number increasing slightly until the Second World War. During the war, multinational corporations other than those of allied and neutral countries had to suspend operations in Japan temporarily, but they resumed business there immediately after the war, and increasing numbers have been

\footnotetext{
1. Tetsuya Kuwahara "Senzen ni okeru gaikokukigyo no tainichi chokusetsu toushi [Foreign Multinationals' Direct Investment in Japan Before WWII]," Kyoto Sangyo University, Keizai Keiei Ronso, 26(2), September 1991. Mira Wilkins "AmericanJapanese Direct Investment Relationships, 1930-1950," Business History Review 56, winter 1982. Mira Wilkins "The Contribution of Foreign Enterprises to Japanese Economic Development," Takeshi Yuzawa and Masaru Udagawa eds., Foreign Business In Japan before WWII, 1993, Tokyo, University of Tokyo Press, 1992. Masaru Udagawa, "Business Management and Foreign-Affiliated Companies in Japan Before World War II,” in Yuzawa and Udagawa eds., op.cit., 1992.
} 
doing business there ever since. During the economic miracle days, many multinational corporations were already active in Japan. In 1967, immediately before the liberalization of foreign investment, 457 of the world's 500 largest industrial companies by sales were foreign, and of these 133 were conducting business in Japan. In 2002, 398 of the world's 500 largest industrial companies by assets were foreign, and of these 176 had direct investments in Japan. ${ }^{2}$

The business outcomes of multinational corporations operating in Japan were diverse: some companies grew into big business, some companies failed to achieve enough market share, while others withdrew from the market altogether. Most research to date has focused on the fact that, after experiencing good initial performance, progress stagnated and many companies eventually withdrew. Their failure generally being attributed to the closed nature of the Japanese business system and the market. ${ }^{3}$ However, the actual management situation of foreign companies still remains unexamined. It is questionable whether there in fact exists a foreign market in which it is as easy for multinational corporations to do business as in their home country. Bearing strong sympathy with this point of view, this paper aims to clarify the entry process of multinational corporations to the Japanese market and their management in Japan.

This paper examines the activities of multinational corporations from abroad in post-war Japan. A characteristic of the post-war Japanese economic system lies in the completion of the catch-up to, and then the surpassing of the advanced industrialized countries in the manufacturing industries. High economic growth was achieved through this process, giving rise concurrently to a society of mass consumption. Multinational food corporations played a major role in the formation of this massconsumption society. In 1967, of the above-mentioned 133 companies with direct investments in Japan, 14 were food companies. I examine the case of General Foods Corporation (GFC), the pioneer company of the instant coffee production in Japan. At the time, GFC was the largest

2. Tetsuya Kuwahara "Dainijisekaitaisengo no takokusekikigyo no tainichi chokusetsu toushi katei [Processes of multinational corporations' FDI in Japan after WWII]," Kokuminkeizai Zasshi, 196(1), July 2007.

3. Mark Mason, American Multinationals and Japan, Cambridge, Harvard University Press, 1993. 
processed foods company in the United States and ranked as the 52ndlargest company in the world by sales.

What is managerial capabilities required for multinational enterprises to succeed in a host country? It is not possible to establish a position in local economy simply by transferring competitive management resources of technology and marketing, developed by the corporations in the home countries, by enforcing them unaltered upon the local market. It is required to adapt these resources to local situations. In this process, creative local management is indispensable. With this perspective, I explore the local operations of GFC in Japan and the performance.

The principal materials used in this paper are recorded interviews with domestic and foreign parties involved in management, primary sources revealed to the author on the occasion of those interviews and their personal letters from interviewees. Interviews were carried out with 31 individuals: three from the headquarters of GFC, twelve from the Japanese subsidiary of GFC, General Foods Limited (GFL), one from Zeneraru Shokuhin Hanbai (GSH) (General Foods Sales Company, Limited), four from Ajinomoto Company, Incorporated, two from Boston Consulting Group Japan branch, one from Hakuhodo Inc., and five from Nestlé. Many of the individuals were interviewed on multiple occasions. ${ }^{4}$ The media of recorded voice of interviewees and the letters from them are reserved by the author.

\section{THE INTERNATIONALIZATION OF GFC AND THE JAPANESE OPERATION}

\section{Internationalization}

The Postum Company was established in 1885 , and while continuing growth as a producer of cereal and oatmeal, in the late 1920s also became a full line producer of processed foods through mergers and acquisitions, in 1928 renaming itself General Foods Corporation. ${ }^{5}$

4. List of interviewees is on table 1 in Tetsuya Kuwahara "Takokusekikigyo no tainichi shinshutsu to soshiki nouryoku no keisei: Zeneraru Foods no ryutsuu seisaku [Foreign Multinationals' in Japan and Their Oranizatinal Capabilities: General Foods in the Economics Miracle Days]," Kobe University, Kokumin Keizai Zasshi, 192(4), October 2005.

5. GFC, Annual Report, Fiscal 1929. GFC, Annual Report, Fiscal, 1931. Eugene Ferguson, General Food Corporation Chronicle of Consumer Satisfaction, The Newcomen Society of the United States, 1985. 
Subsequently the company continued to promote diversification and acquisitions, and prior to World War II had already established itself as the largest processed food company in the United States. Through the process of implementing full line product strategy, for some time GFC took a centralized functional structure, but in the 1940s the company began to institute separate product divisions, and by 1946 it established a full fledged product divisional structure of sixteen such product divisions.

After World War II, in addition to product diversification through acquisitions, GFC began aggressively expanding foreign direct investment. The company's only overseas assets prior to World War II were factories in Canada and a supply base of coconuts in the Philippines; however, after the war it implemented a major geographical expansion strategy. Charles Mortimer, appointed company president in 1954, and having a sense of mission to supply GFC's processed foods to the world, proceeded aggressively with foreign investment. By March 1967, the company had production facilities in 17 countries. ${ }^{6}$ The same year, overseas operations and exports accounted for 13 percent of GFC's total sales (not including 6 percent from Canada). However, overseas profits remained low, accounting for a mere 7.5 percent of corporate profits (not including Canada).

\section{Entry in Japan}

GFC began direct investment in Japan in 1953, but this was not the company's first activity in the Japanese market. The company was already supplying American forces with Bireley's orange juice during the post-war occupation period and when sales on the civilian market were permitted from 1950, GFC began to export the concentrated product to Japan. ${ }^{7}$ Bireley's orange juice concentrate was bottled at a plant of the Wilkinson Carbonated Spring Water Company, Takarazuka, Hyogo Prefecture and sold nationwide at retailers in the Asahi Beer Kaisha (Asahi Breweries Ltd.) sales network. Bireley's orange juice was

6. GFC, Annual Report, Fiscal 1967.

7. Ichirou Tsukuura interview, Tokyo, 4 March 2004. Ichirou Tsukuura "Ichiro Tsukuura memo in 1950s 1960s" reserved by the author. Sadahiro Yonai interview, Tokyo, 24 June 2003, 18 July 2003, 20 August 2003. Asahi Beer Kaisha, Asahi 100, August 1990, p38. 
the first fruit juice drink whose main ingredient was orange sold in Japan. Following its introduction, juice beverages of many brands appeared on the market.

In 1953, the Japanese government banned imports of orange juice concentrate in order to protect mandarin orange farmers. In response, GFC established the 100 percent-owned subsidiary General Foods Limited (GFL) with capital of 46 million yen in Itami City, Hyogo Prefecture. ${ }^{8}$ GFL was a foreign company under the yen base company law, and as such could not remit principal, interest and dividend to the home country. GFC dispatched an engineer as GFL's president. In addition, two Japanese engineers were employed, becoming the main overseers of construction and operation of the plant. The mandarin oranges which were the principal ingredient were sourced from, among other areas, Wakayama, Ehime and Shizuoka Prefectures. In the mandarin harvesting season, approximately 100 seasonal workers were employed to produce the concentrate, which was stored in large drums and sent to the Wilkinson Carbonated Spring Water Company for bottling. Asahi Breweries was in charge of the sale of the juice. Bireley's Orange Juice established itself as the leading brand of fruit juice drink. In 1957, the total national juice consumption was 320 million cases, of which Bireley's orange juice accounted for 180 million cases (56 percent). ${ }^{9}$

As Japan entered the economic miracle days, and in a somewhat more favorable balance of foreign exchange, import liberalization policy was started and it permitted the import of green coffee (raw coffee beans) in 1960. That year, green coffee imports surpassed the prewar peak levels of 1937. A massive demand for roasted coffee was created when coffee shops sprang up in cities across the country in response to this opportunity. Liberalization of the import of instant coffee came in 1961, and demand consequently soared.

Demand for instant coffee was 19,860 tons in 1965 (Table 1), surpassing even demand for roasted coffee of 17,927 tons the same year.

As green coffee imports were liberalized, GFC planned the

8. Nobuo Takaoki interview, Tokyo, 24 October 2003. Nobuo Takaoki, "Makuseru ni rekishi ari [The history of Maxwell] No. 5," AGF, AGF News, August 1983.

9. Nikkan Keizai Tsuushinsha, Shurui schokuhin sangyou no seisan hanbai shea (Production and Market Shares of Alcholic Biverages and Foods), 1981. 
Table 1: Instant coffee market size

Unit: tons

\begin{tabular}{|c|c|c|c|}
\hline Year & Import & Production & Total supply \\
\hline 1956 & 24 & 0 & 24 \\
\hline 1957 & n.a. & 0 & n.a. \\
\hline 1958 & n.a. & 0 & n.a. \\
\hline 1959 & n.a. & 0 & n.a. \\
\hline 1960 & 28 & 150 & 178 \\
\hline 1961 & 1,515 & 1,100 & 2,615 \\
\hline 1962 & 2,745 & 1,100 & 3,845 \\
\hline 1963 & 2,845 & 1,200 & 4,045 \\
\hline 1964 & 3,168 & 1,200 & 4,368 \\
\hline 1965 & 3,512 & 1,500 & 5,012 \\
\hline 1966 & 1,620 & 5,000 & 6,620 \\
\hline 1967 & 799 & 7,300 & 8,099 \\
\hline 1968 & 1,456 & 7,869 & 9,325 \\
\hline 1969 & 2,279 & 8,472 & 10,751 \\
\hline 1970 & 2,970 & 9,592 & 12,562 \\
\hline 1971 & 2,679 & 12,812 & 15,491 \\
\hline 1972 & 1,834 & 14,196 & 16,030 \\
\hline 1973 & 1,205 & 13,784 & 14,989 \\
\hline 1974 & 3,745 & 21,408 & 25,153 \\
\hline 1975 & 4,108 & 21,387 & 25,495 \\
\hline 1974 & 3,745 & 21,408 & 25,153 \\
\hline 1975 & 4,108 & 21,387 & 25,495 \\
\hline 1976 & 3,959 & 22,894 & 26,853 \\
\hline 1977 & 4,913 & 19,707 & 24,620 \\
\hline 1978 & 3,521 & 19,169 & 22,690 \\
\hline 1979 & 8,373 & 26,917 & 35,290 \\
\hline 1980 & 6,333 & 25,089 & 31,422 \\
\hline 1981 & 6,785 & 26,472 & 33,257 \\
\hline 1982 & 7,291 & 29,345 & 36,636 \\
\hline 1983 & 7,163 & 30,069 & 37,232 \\
\hline 1984 & 7,361 & 32,224 & 39,585 \\
\hline 1985 & 6,038 & 33,005 & 39,043 \\
\hline 1986 & 6,794 & 34,639 & 41,433 \\
\hline 1987 & 6,705 & 35,603 & 42,308 \\
\hline 1988 & 8,019 & 36,727 & 44,746 \\
\hline
\end{tabular}

Source: Nihon Insutanto Ko-hi Kyoukai (Japan Instant Coffee Association), Insutanto Ko-hi Shoushi (A short history of instant coffee), 1995. 
construction of an instant coffee plant. Under the direction of an engineer sent from GFC, the two Japanese engineers who had overseen Bireley's orange juice production and one Japanese engineer who was employed in April 1960 participated in the construction of the plant. ${ }^{10}$ In November 1960 at the Itami factory, construction of an instant coffee production line with a daily production of 25 tons was completed, and trial production began. Early runs experienced problems including charring of coffee beans during processing, but through trial and errors stable production quality was eventually achieved. Full-scale production of instant coffee started the following month, and on December 5, the first shipment left the company warehouse in Shinagawa, Tokyo. The following year, the second production line with the same capacity was constructed within the Itami factory, doubling capacity.

As Morinaga Seika Kaisha (Morinaga Confectionary Co.) had already started production of instant coffee at its Mishima Plant in September 1960, so GFC was the second domestic producer. The third manufacturer, Meiji Seika Kaisha (meiji Confectionary Co.), started production in August 1962. ${ }^{11}$ During this period, with the start of import liberalization, Nestlé and numerous other foreign manufacturers entered the Japanese market of instant coffee en masse by export strategy. In 1962, that number of their brands was said to be some 70 to 80 .

\section{MASS MARKETING OF INSTANT COFFEE}

1. Transferring the product manager system to GFL

GFC aimed to build a dominant market position in Japan through full use of product technology and marketing management. Based on surveys of consumer preferences, GFC improved the quality of its coffee. The company aimed also to introduce its full range of processed food products to the Japanese market. The powder dessert mix whose brand name was "Pudi" was introduced in 1963, and in 1966 the powder sauce mix "Lumikku" was introduced and development of powder mix of salad dressing began. ${ }^{12}$

10. Nobuo Takaoki, op.cit. AGF, AGF News, 1984.

11. In 1972, Meiji Seika withdrew from the instant coffee market. As of 1977, Morinaga only produced instant coffee for use as an ingredient for sweets.

12. Tetsuo Arima interview, Miyazaki, 2 November 2002. 
In 1961, GFC sent J. Whitcomb in an attempt to introduce mass marketing knowhow, and under his direction Japanese staff were trained as product managers. Until the commencement of a regular graduate recruitment intake in 1968, these Japanese managerial staff were midcareer workers, highly educated and fluent in English. Many were motivated to join the company by its status as the largest food company in the world. A program director from TV Asahi was employed as advertising director, ${ }^{13}$ another individual from Showa Petroleum Company was employed as a product manager for "Maxwell," and the account manager for Maxwell of advertising agency Hakuhodo Inc. was invited a product manager for the new product "Pudi."

Product manager system was an organizational means of improving market adaptation of each product. With this system market research, product development, production, sales, advertising, and performance measurement for each product was controlled under a single manager. Product managers continuously monitored the market, examining consumer tastes, sales outcome and competitor activities.

The company also made active use of research agencies to obtain market data. Based on this scientific research, GFL was able to build product specifications tailored to the tastes of consumers, and to implement advertising and sales promotions. Managers could then control their products by comparing actual sales data to the initial plan. ${ }^{14}$ In 1963, the GFL marketing department, in order to enhance the image of Maxwell, changed the shape of the jar and changed the color of the label from red to a burnt brown color. Additionally, between 1965 and 1968, an actor Tatsuya Mihashi was used as an advertising character figure in an effort to improve the brand image. Advertising expense in the 1968-9 financial year, while still less than Nestlé's expenditure, reached 400 million yen. ${ }^{15}$

13. Hiroshi Enomoto interview, 30 November 2002, 19 April 2003, 18 August 2003. These interviews were conducted in Tokyo.

14. Whether the focus on such research actually led to results was more ore less questionable. Managers were not always to be able to read the reality behind statistics. Moreover, the numerical numbers supplied were not always inadequate, and it has been said that there was a tendency to use the numbers in such a way to execuse their inability to produce a good result. Hiroshi Enomoto interview, Tokyo, 30 November, 2002.

15. Sadahiro Yonai, "Kōkoku ni koi shite: nessuru to tatakau otoko [In love with advertisements: the man who took on Nestlé]," Burein (Brain), November 1990. 
GFL has attracted attention as a leader in the marketing of consumer goods in Japan. The company, by its training of product managers and employment of innovative marketing techniques, was referred to as the "GF School." However, no small number of the Japanese managers who acquired such management knowledge at the company quit GFL several years later. Such managers moved on to become directors or managers, mainly at Japanese subsidiaries of foreign multinational corporations entering the Japanese market. This movement of staff contributed to spread GFC's marketing techniques out the Japanese consumer goods industry. However, this also means that GFC's attempts to retain trained of Japanese managers were not successful.

\section{Trial and Errors in Sales}

Historically, the food distribution channels in Japan was constructed, and functioned as an institution embedded in society. If a manufacturer was not able to utilize this system properly, it would never gain access to the shelves of the more than one million retail outlets across the country. For this reason, Zeneraru Shokuhin Hanbai Kaisha (GSH) (General Foods Sales Company, Limited) was formed in December 1961 with capital of 2.5 million yen to be in charge of distribution of GFL's instant coffee. ${ }^{16}$ GSH ownership was split equally between the Asahi Beer Company and the Wilkinson Carbonated Spring Water Company. Through the distribution of Bireley's orange juice, GFL had experienced working with both companies.

GFL used GSH as their sole agent for wholesalers and all instant coffee produced was passed to this company. In this way, GFL was able to avoid the burden of managing its own sales operation.

GSH sold through a traditional wholesale network, entrusting sales to retail outlets entirely to regional wholesalers. GSH by itself never made access to retailers. However, this form of distribution immediately found itself in a weaker position relative to the strategy of direct access to retailers, being deployed countrywide by Nestlé. Ahead of GSH, Nestlé approached retail outlets and acquired the display cases of retailers. When one brand was placed in the display case and shelves in a retailer

16. Ichirou Tsukuura interview, Tokyo, 4 March 2004. Ichirou Tsukuura, memo in 1950s-1960s" reserved by the author. 
there was no space for other brands, as a result of which Nescafé was on display at more retailers than Maxwell. Even if Maxwell was also on sale at retail stores, it was relegated to an inconspicuous location or provided with smaller display space. As Maxwell was slow to be sold at retail outlets, wholesalers was not willing to deal with GSH.

Meanwhile, one and a half years from its initial release, and just as it had become normal countrywide for retail outlets to stock instant coffee, solidification of the powder in the jar happened. ${ }^{17}$ In the summer of 1962, there were complaints from retailers around the country that instant coffee was caked in the jar. Moisture entering the jar through the lid was causing the instant coffee to be solidified in Japan's high humid summers. This problem affected the products of all manufacturers. GFL quickly dealt with this problem by developing a seal to cut moisture penetration into jar, preventing caking of the instant coffee. However, the recall of solidified Maxwell on retailers' shelves was much delayed, in the end taking far longer than Nestlé and consequently having a negative reputation on Maxwell's image as a quality product. ${ }^{18}$

In the fierce competition between the seventy or eighty instant coffee brands in the market, Maxwell's market share fell rapidly from 42 percent in spring 1961, to 10.7 percent by 1964 . (Table 2) The brand that achieved a dominant market share in that time was Nescafé.

GFL left functions of distribution of instant coffee to GSH formed by Asahi Breweries and Wilkinson. This distribution strategy was not workable. In contrast, the efficacy of Nestlé's strategy approaching themselves to retailers over Japan was realized, while taking advantages of utilizing the traditional distribution channel for logistics and collecting bills. GFL management recognized that a foray into retail sales was necessary in GFL's competition with Nestlé. ${ }^{19}$ In April 1964, GFL began working directly on retailers. GFL's retail sales force were called "Customer Service," and by October 1964, twenty staff were recruited at sales office in Tokyo, four in Nagoya, and thirteen in

17. Arima Tetsuo interview, Miyazaki, 2 November 2002. Takaoki Nobuo interview, Tokyo, 24 January 2003.

18. However, this issue should be considered as a temporary problem. Takaoki Nobuo interview, Tokyo, 24 January 2003.

19. Interview with Ryohei Tanaka, Joji Shigematsu, and Kengo Soeda. It was conducted in Kobe, 16 January 2002. 


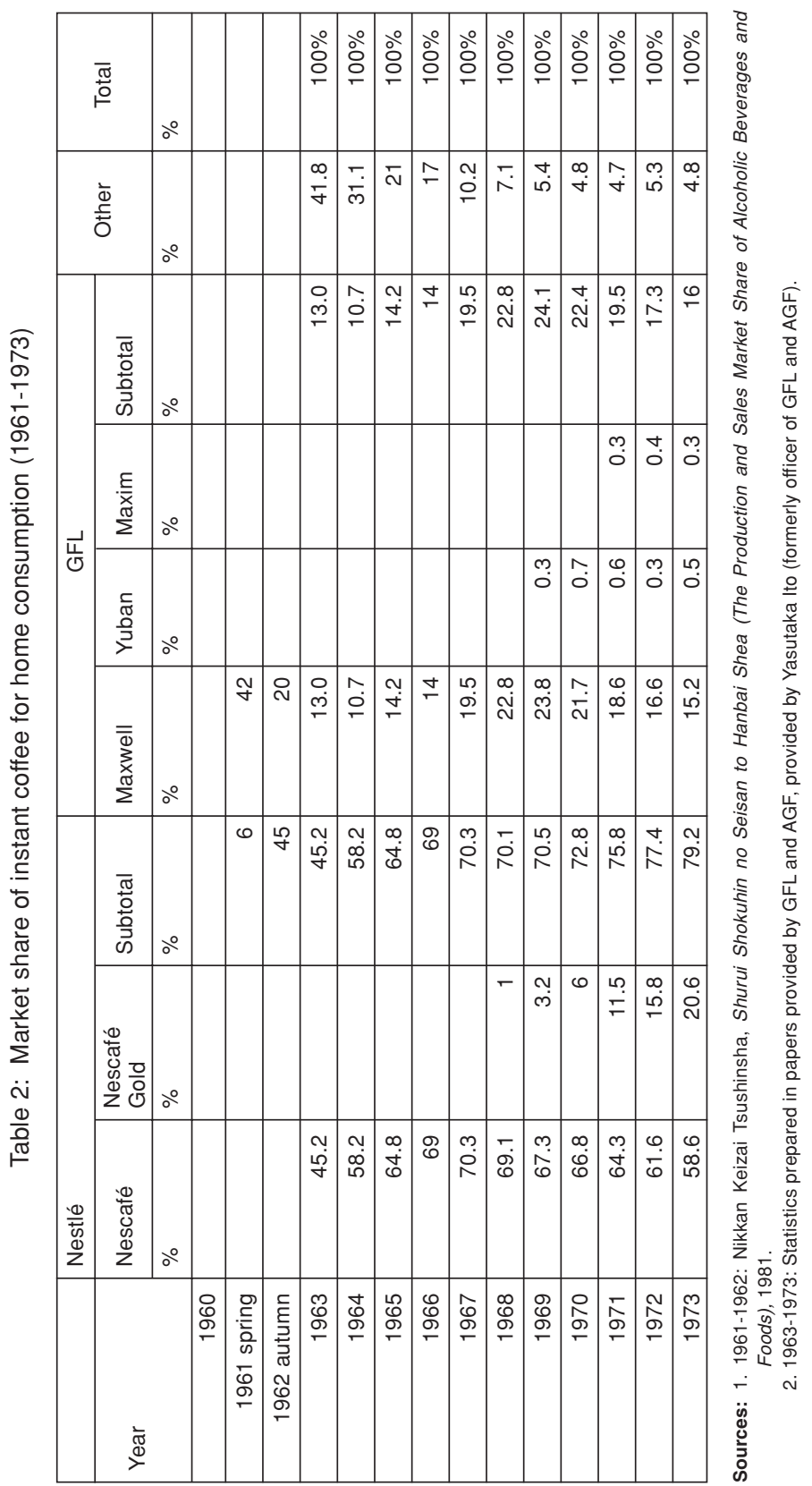


Osaka. ${ }^{20}$ This retail sales force was by no means large, and so moved in an agile fashion in selected target areas, focusing its sales efforts on the retail outlets that had not sold Maxwell on shelves yet.

In October 1965, GFL acquired GSH, including approximately 130 employees, sales offices throughout the country, vehicles, and commercial rights, for a total of 300 million yen. A sales headquarters was established in GFL's Tokyo head office to manage the countrywide sales network. ${ }^{21}$ In response to a need for funding for this activity, in November 1966, GFL increased its capital by 576.977 million yen to 622.697 million yen.

3. Underdeveloped international managerial personnel

After World War II, GFC actively continued its foreign direct investment, but foreign business was never given more than a peripheral position within the company. The International Division was conceived of as a department peripheral to the domestic product divisions. ${ }^{22}$ As a result, GFC's human resources management for international staff failed to develop. It has been reported that within the company's human resources management, a transfer to the International Division was seen as a career dead end, ${ }^{23}$ and there is evidence that working abroad signified the end of promotion. If one follows the careers of twenty three staff who worked overseas for GFC during the years 1960-64, sixteen employees (70 percent of total 23) left the company. Only seven staff returned to the company, and only five ( 22 percent) were promoted to a higher position than they held before expatriate experience, while two staff were not promoted at all compared to their position before foreign service. Under these conditions, staff were reluctant to accept overseas positions, and under such human resource management the

20. Tetsuji Kishi, "Makuseru ni rekishi ari [The history of Maxwell] No.3," AGF, AGF News, 1983. Tetsuji Kishi, "Makuseru ni rekishi ari [The history of Maxwell] No.4," AGF, AGF News, 1983.

21. Hiroshi Enomoto interview, Tokyo, 19 April 2003, and Tokyo, 18 August 2004. Ichirou Tsukuura interview, Tokyo, 4 March 2003. Tsukuura op.cit., 1950s 60s.

22. Adolf Clausi interview, Stamford, Connecticut, 8 and 20 March 2003. James Stone interview, Sarasota, Florida, 20-22 March 2003. Stone relates that overseas business was a something like a hobby for GFC.

23. Harvard Business School, "General Foods Corporation-International Division (J1): Problems in Executive Manpower," Case Services, 9-3-1-218, 1965. 
development and accumulation of international personnel did not proceed well.

The careers of GFC employees dispatched to Japan closely followed the pattern described above. There were thirteen staff stationed in Japan for at least one year from 1960-72 (Table 3), during which period the stage of life cycle of instant coffee in Japan, was at the new one to the growth one. Most of them were Americans. Of those 12 staff not including one who died during stay in Japan, two (17 percent of the total 12) was posted for one year, two for two years, five ( 42 percent) for three years, two for four years, and one ( 8 percent) for six years. Their service length for local operation in Japan is considered too short to be familiar with Japanese business environment.

We can also follow the careers of the ten officers of total thirteen, after completing their stay in Japan. The data of the other two persons was not available and the remaining one person dead in Japan. Out of total ten persons only five continued their career in GFC. The other five left the company when their posting was completed, suggesting that a management position in GFL was not an appointment that promised a future at GFC. Comparing with their competitor Nestlé, GFC's retention rate of officers dispatched to Japan was much lower. In Nestlé twenty two officers stationed in Japan during years 1960 1972. ${ }^{24}$ One person died during his career with Japanese subsidiary. The other twenty one continued their career within Nestlé until their retirement age. Five returned back to the head office in Vevey, Switzerland. Nine were transferred to the subsidiaries in the third countries, seven continued their posts in Japan until their retirement age, and their career in Japan was on the usual track of international appointment in Nestlé. Their understandings and being familiar with Japanese market and distribution was more profound than those of GFL officers, and their commitment to the Japanese operation was considered deeper.

Under such human resource management at GFC, long-term postings to Japan were disliked. In the context of the expanding mass market in Japan, GFL was never able to develop staff capable of comprehending Japanese foodstuffs consumption, home eating habits, and everyday

24. Tetsuya Kuwahara, "Takokusekikigyo no Genchi Keiei to "Nestlé", Tyuuzaiin Seisaku (Local operation of Foreign Multinationals in Japan and their Expatriate Policy", Kobe University, Kokumin Keizai Zassi, 194(4), April, 2008. 


\begin{tabular}{|c|c|c|c|c|c|c|c|c|c|}
\hline $\begin{array}{l}\stackrel{\infty}{\infty} \\
\stackrel{0}{0}\end{array}$ & & 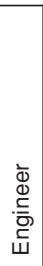 & 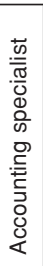 & 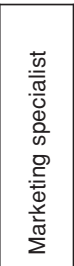 & 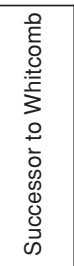 & 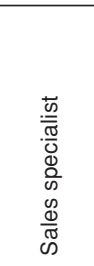 & 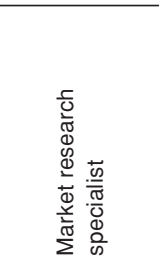 & 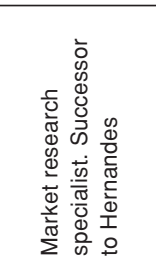 & 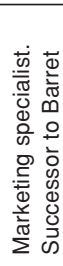 \\
\hline 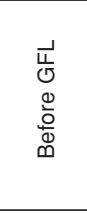 & & & $\begin{array}{l}\text { U } \\
\text { U. }\end{array}$ & $\begin{array}{l}\text { U } \\
\text { U. }\end{array}$ & $\begin{array}{l}\text { U } \\
\text { U. }\end{array}$ & 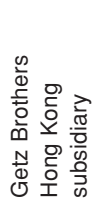 & $\begin{array}{l}0 \\
\text { U. } \\
\text { L }\end{array}$ & 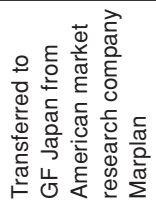 & $\begin{array}{l}\text { U } \\
\text { U. }\end{array}$ \\
\hline 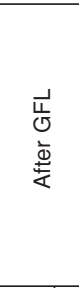 & & & $\begin{array}{l}0 \\
\mathbb{W}\end{array}$ & 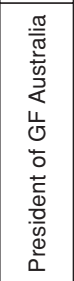 & 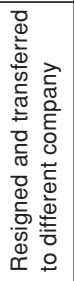 & 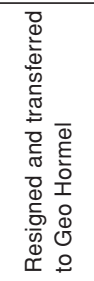 & $\begin{array}{l}\text { D. } \\
.0\end{array}$ & 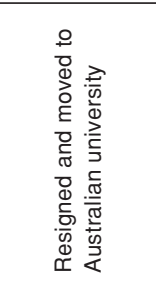 & 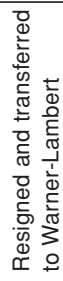 \\
\hline 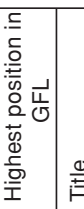 & $\begin{array}{l}\frac{\vec{c}}{0} \\
\frac{0}{0} \\
\frac{0}{0} \\
\frac{1}{2}\end{array}$ & 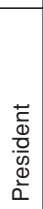 & 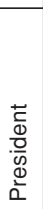 & 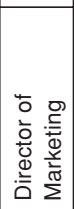 & 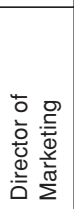 & $\begin{array}{l}\text { प्र } \\
\frac{0}{0} \\
\frac{0}{0} \\
\frac{0}{2} \\
0\end{array}$ & 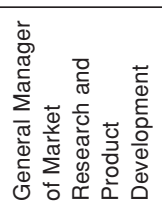 & 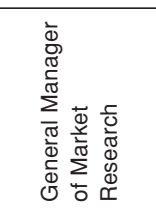 & 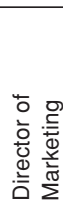 \\
\hline \multirow{3}{*}{ 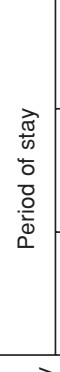 } & 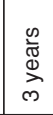 & $\begin{array}{l}\bar{\Phi} \\
\stackrel{\varpi}{\perp}\end{array}$ & $\begin{array}{l}\stackrel{\infty}{\mathbb{N}} \\
\stackrel{\infty}{\infty} \\
\stackrel{\infty}{\infty}\end{array}$ & $\underset{\substack{\infty \\
\infty}}{\stackrel{\infty}{\infty}}$ & $\begin{array}{l}\stackrel{\infty}{\infty} \\
\stackrel{\infty}{\infty} \\
\stackrel{\sim}{N}\end{array}$ & 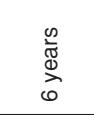 & $\underset{\infty}{\stackrel{\infty}{\infty}}$ & 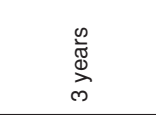 & 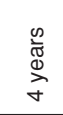 \\
\hline & $\begin{array}{l}\bar{\oplus} \\
\end{array}$ & 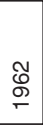 & $\begin{array}{l}\stackrel{\llcorner}{\circ} \\
\stackrel{\circ}{\leftarrow} \\
\end{array}$ & $\begin{array}{l}\text { む্ } \\
\stackrel{\circ}{\circ}\end{array}$ & 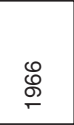 & $\begin{array}{l}\text { م } \\
\text { o } \\
\frac{0}{0} \\
\stackrel{0}{0}\end{array}$ & $\begin{array}{l}\hat{\theta} \\
\mathscr{\sigma} \\
\overline{0} \\
0\end{array}$ & $\begin{array}{l}\text { ㅇ } \\
\text { م }\end{array}$ & 六 \\
\hline & 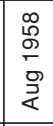 & $\begin{array}{l}\overline{6} \\
0 \\
\overline{5} \\
\end{array}$ & $\begin{array}{l}\text { ષै } \\
\stackrel{\circ}{\leftarrow} \\
\end{array}$ & ¿্口 & 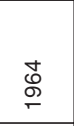 & $\begin{array}{l}\text { Jे } \\
\text { o } \\
\frac{\pi}{\pi} \\
\Sigma\end{array}$ & 志 & $\begin{array}{l}\widehat{\phi} \\
\stackrel{\sigma}{\sigma}\end{array}$ & $\begin{array}{l}\widehat{o} \\
\stackrel{\circ}{\circ}\end{array}$ \\
\hline 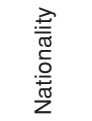 & 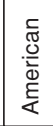 & 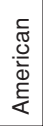 & 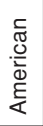 & 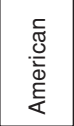 & 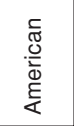 & 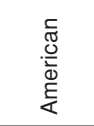 & 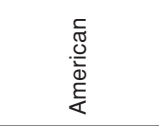 & 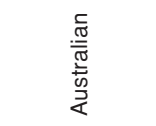 & 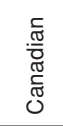 \\
\hline $\begin{array}{l}\stackrel{\oplus}{E} \\
\stackrel{\mathbb{\pi}}{Z}\end{array}$ & 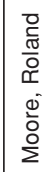 & $\begin{array}{l}0 \\
\Phi \\
0 \\
\sum \\
\Sigma\end{array}$ & $\begin{array}{l}\dot{0} \\
\dot{D} \\
\frac{\omega}{x} \\
\dot{5} \\
\dot{5}\end{array}$ & 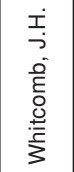 & 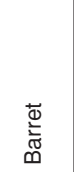 & 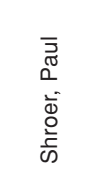 & $\begin{array}{l}\dot{j} \\
0 \\
0 \\
0 \\
0 \\
\frac{1}{0} \\
\stackrel{0}{0} \\
\frac{1}{1}\end{array}$ & 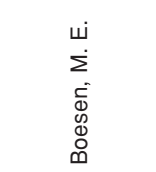 & 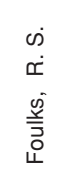 \\
\hline
\end{tabular}




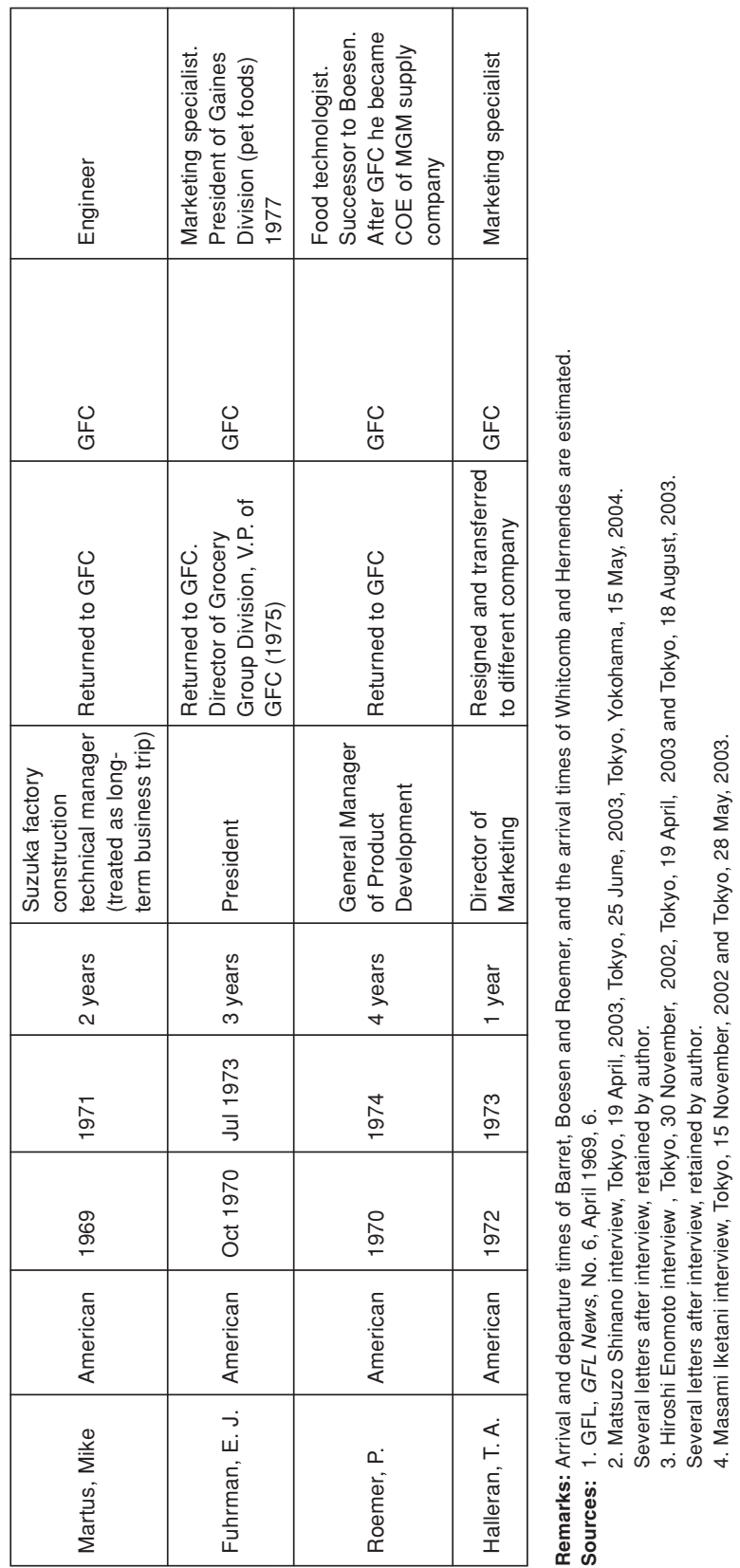


lifestyle, and the Japanese wholesale distribution system. There were also no staff at the headquarters of GFC who could understand the Japanese company. The lack of global understanding among the top management of GFC and the underdevelopment of international human resource management made the international expansion significantly more difficult than it might have been.

As mentioned above, between 1964 and 1965, GFL internalized sales and was in charge of directly approaching distribution channels. However, there were no staff in GFC responsible for GFL of multiple functions including sales. Consequently, GFC could not help recruiting qualified personnel for Japanese operation from outside the company. For this purpose, they employed Paul Schröer, sales manager at the Hong Kong subsidiary of Getz Brothers, a major foods company headquartered in Chicago. Schröer was a specialist in sales and, having achieved excellent results in Hong Kong, GFC's top management noted his sales ability, believing in that he would be able to resolve the distribution problems in the Far East. In the spring of 1964 Schröer was appointed sales manager at GFL and from 1965 was promoted upward president of the company.

\section{DISTRIBUTION FAILURES}

1. The sales strategy to wholesalers

As the market expanded rapidly, GFL devoted its full effort to increasing sales volume and recovering market share. Schröer, an expert in sales to wholesalers, offered large rebates during price negotiations with wholesalers in an attempt to increase sales volumes. Promotional packs like as increased volume jars were aggressively pushed. These sales promotions, while temporary, appeared to be successful on the surface as GFL's market share rose to 24 percent in 1969.

However, excessive sales promotion also carried with it the risk of lowering Maxwell's brand value.

In the Japanese instant coffee industry, by the late 1960s just two companies were major players. Of the two, GFL was located in distant second position, well behind Nestlé, the dominant player. GFL was in a less favorable position than Nestlé to achieve economies of scale. While having just one-third of the production capacity of Nestlé, GFL also 
suffered from higher per-unit production costs. Despite suffering from these disadvantages, GFL attempted to engage in price competition to increase sales volume. However, much of instant coffee sold to wholesalers under the rebate scheme ended up as stock in their warehouses. The wholesalers carrying excessive Maxwell stock sold it at a sacrifice beyond their business territories. In the face of underselling by wholesalers, retail prices fell. The sales problems at the time have been described as follows. "The Maxwell retail price was traditionally lower than that of Nescafé. Selling it cheaply means that you end up paying more of a subsidy than the leading brand Nescafé. People in charge of sales would regularly request promotion funds for the day's sales, and management tended to accept their demands." 25 The substantial proportion of instant coffee in particular, 63 percent in 1966, was sold through supermarkets. ${ }^{26}$ Maxwell came to be used as such a bargain product by supermarkets, as a result of which, Maxwell's share of supermarket sales was significantly higher than the other brands. ${ }^{27}$ "This historically long underselling of coffee, rather than arising from the will of manufacturers or consumers, was deployed as a means to expand sales by distribution companies." 28 To prevent underselling of Maxwell under competition among wholesalers, GFL recognized it was necessary to decrease the agents. Substantial number of wholesalers lack of sufficient selling power were excluded from member list of agents. In 1968 wholesalers of special contract with GFL decreased from 100 to 71 companies, by January 1969 to 42 companies, and by January 1971 to 17 companies. $^{29}$

When it became clear that year-end targets would not be met, stock was pushed on to wholesalers, in effect creating earnings without sales. While it was common practice in the industry in order to meet year-end targets, GFL made excessive use of this measure. Once the income

25. Sadahiro Yonai, op.cit., November 1990, p105.

26. Nikkan Keizai Tsuushinsha, "Shurui Shokuhin no Seisan to Hanbai Shea (The Production [The Production and Market Share of Alcoholic Beverages and Foods], 1967. Shakai-chousa Kenkyu sho, "SCI Report", Dec. 1919.

27. Tetsuji Kishi, "Makuseru ni rekishi ari [The history of Maxwell] No.3," AGF, AGF News, 1983.

28. Sadahiro Yonai, "Ko-hi no bijinesu to kōkoku: 1950nen igo [Advertising and the coffee business since 1950]," Nihon Koohii Kyoukai, Koohii Bunka, vol. 1.

29. Hiroshi Enomoto interview, Tokyo, 19 April 2003 and Tokyo, 18 August 2003. 
target was approved by GFC headquarters at the start of the year, it had to be followed strictly. In cases where sales and profit targets could not be met, GFL was forced to adopt such financial measures to an excessive degree. Even worse Schröer had no personal connections with the top management of GFC, and for this and other reasons, it is possible that top management would not have been sympathetic to explanations of the difficult situation in Japan, and he would be limited to explaining performance on the basis of figures alone. This context was the origin of the financial measures of earnings without sales for showing satisfactory results at the end of year.

\section{Collapse of brand status of Maxwell}

When special offers and low price sales were implemented at the final point of sale, the unit sales price of GFL instant coffee fell, resulting in reduced gross margins and a reduced advertising budget. In the mid 1970s, GFL had to retire as sponsor of the TBS TV series "Yoru no hitto sutajio" (Evening Hit Studio), then enjoying the highest viewing figures of any program on television. Under these circumstances, being relatively inexpensive and offering an immediate impact on sales, promotional packs came to be offered on an almost continuous basis. One former sales manager recalls that he was appalled to see several different Maxwell promotional packs displayed together on the shelves of retailers in provincial cities. ${ }^{30}$ Thus, the situation arose that it was difficult to sell Maxwell instant coffee without giving out promotional packs.

GFL's market difficulties were mirrored in productivity issues. GFL productivity was low. In the years 1969-72, GFL's per capita sales (yearly average sales from 1969 to 1971 , divided by the 1970 average number of employees) were 10.446 million yen against 30.841 million yen for Nestlé, ${ }^{31}$ just one-third of Nestlé's level. This indicates that the GFL product, despite high production costs, was being sold at low prices. In January 1970, Schröer stated that, "Despite the expansion of human and physical resources, company profitability has been declining

30. Tetsuji Kishi, "Makkusuueru ni rekishi ari [The history of Maxwell] No.4," AGF, AGF News, 1983.

31. Tadao Matsumura interview, Tokyo, 17 July 2003. 
for the past few years." 32 While the profit margin on sales for fiscal 1968 (April 1968-March 1969) was 7.3 percent, by fiscal 1970 (April 1970-March 1971) this had dropped to 2.6 percent. Market share peaked in 1969 at 24 percent, as described above, declining to 22 percent the following year, 19 percent in 1971 and 17 percent in 1972. Total sales to the end of fiscal 1972 fell from 7.8 billion yen the previous year to 5.4 billion yen, plunging 1.4 billion yen into the red. This deficit was roughly equal to the total net profit from instant coffee from the beginning until the year. ${ }^{33}$

\section{REORGANIZATION TO A JOINT VENTURE}

In October 1970, GFC appointed Edward Fuhrman as president of GFL. His prior position had been vice president of marketing for the Maxwell House division in White Plain, New York. It was unusual for a young manager who had been promoted within the domestic products division to be appointed as a foreign representative. Fuhrman was sounded out for a two-year appointment in Japan by G. Bremser, president of General Foods International. ${ }^{34} \mathrm{He}$ was told, "This will be a totally new experience and opportunity in preparation for becoming a future executive." His friends and acquaintances, fearing for his future career, opposed his posting to Japan. Consequently, he accepted the position from GFC President Eugene Ferguson on the condition that on completion of his two years in Japan, an appropriate position would be prepared for him on return to headquarters. Fuhrman was the first person from core GFC management to be sent to GFL, and Japanese employees of GFL welcomed his arrival as a sign that GFC was finally about to begin work in earnest on their Japanese business. ${ }^{35}$

Soon after his arrival, Fuhrman became aware of the stock-offloading to wholesalers and the large amount of stock. He prohibited the excessive use of rebates as a sales strategy and year-end practices such

32. Paul Schröer, "Juugyouin no minasan e, 1970nen no nentou ni sai site [Dear employees, some considerations for the 1970s]", GF News, No.8, January 1970.

33. Tadao Matsumura interview, Tokyo, 17 July 2003.

34. E. Fuhrman interview, Stamford, Connecticut, 9 March 2003.

35. Matsuzo Shinano interview, Tokyo, 15 May 2004 and Yokohama, 19 December 2004. 
as earnings without sales. Further, he worked to dispose of excess inventory and to prevent underselling, and moreover planned diversification into promising new businesses. In November 1970, the newly completed plant in Suzuka was brought online, introducing granulated instant coffee to the market. This new product was regarded as able to appeal to consumers as more up product market than the usual Maxwell product, and of competing with Nestlé's freeze-dried instant coffee "Nescafé Gold Blend". However, sales did not rise to meet expectations. Somewhat distant from its image as a coffee producer, GFL undertook diversification to the dog food, whose brand name was Gaine's Meal. They recognized a good chance of achieving a position as a first-tier company in the dog food market. Further they began the restaurant chain whose name was Burger Chef." In August 1971, GFC injected an extra 3.6 billion yen of capital into GFL in support of Fuhrman.

However, as noted above, in the fiscal year to March 1972, GFL returned a large loss. This motivated GFC to withdraw from parts of its business in Japan, ${ }^{36}$ and to plan instead the reorganizing GFL to a joint venture with a leading Japanese company. From April to September 1972, the head of the Asia-Pacific region of GFC's international division was posted to Tokyo and started looking for joint venture partners. This restructuring of GFC's Japanese operations were conducted with the advice of the Boston Consulting Group. Initial negotiations regarding a joint venture were conducted with Takeda Yakuhin Kougyo (Takeda Pharmaceutical Co. Ltd.), but failed to come to a conclusion. ${ }^{37} \mathrm{Next}$, negotiations were begun with Ajinomoto, and were concluded in September 1972. As a result, GFC sold a fifty-percent stake in GFL to

36. The not good performance of GFC as a whole affected the decision. "Fiscal 1972 ---- was a disappointing year for all of us in General Foods. Our sales----- continued their upward trend. But our earnings from operations dropped for the first time in 20 years." "The corporation's overseas operations had a disappointing year. Earnings attributable to these businesses were 3.5 million, well below the $\$ 8.1$ million of fiscal 1971.----- the Italian business operated at a loss.--- inflationary cost pressures depressed earnings of GF's Brazilian subsidiary, Kibon. Results in both Australia and Japan were below our expectations as heightened competitive environments as well as cost pressures adversely affected the earnings of these two subsidiaries." GFC, Annual Report, Fiscal 1972.

37. Tadao Matsumura interview, Tokyo 29 May 2003. 
Ajinomoto, with Ajinomoto taking responsibility for sales and marketing, becoming the sole agent for GFL products and appointing the president for the company, while GFC took responsibility for product and production technology and appointed the company vice president. A one-year preparatory period was given, during which period, in January 1973, ten percent of the staff (65 employees) were laid off, leaving a staff of 550 persons. ${ }^{38}$

On August 1, 1973, GFL was reorganized as a joint venture owned 50 percent by GFC and 50 percent by Ajinomoto. ${ }^{39}$ The company's capital was unchanged at 3.8 billion yen. The new company was called Ajinomoto General Foods (AGF). From Ajinomoto, Kiyoshi Takeda (Ajinomoto director, prior Tokyo branch manager) was appointed president, and a senior managing director and two directors were appointed to the board. From GFC, P. Wedepohl (former president of GFC's Venezuela subsidiary) was appointed vice president, and one enior managing director and two technical directors were appointed to the board. Thus, GFC transformed GFL into a joint venture, and except for technical aspects, transferred all other functions and management responsibilities to their business partner Ajinomoto. GFC's opportunities in Japan came to be limited to securing dividend payments and technology licensing. This can be interpreted as the substantial withdrawal of GFC from business activities in Japan. Such poor overseas performance became evident not only in Japan but in many countries where GFC invested. ${ }^{40}$

\section{CONCLUSION}

The above case study allows us to draw the following summary and conclusions.

First, GFC believed that, when investing in Japan, by transferring mass marketing knowhow in particular of product manager system and new product technology, they should be able to establish a good position

38. Sankei Shimbun (Sankei News Paper), 26 January 1973.

39. Nihon Shokuhin Shinbun (Japan Food News), 1 August 1973.

40. The slump in GFC's was not confined to overseas business, but coupled with the failure of diversification strategies within the U.S. GFC's survival was becoming difficult since these years. In 1986, GFC was acquired by Phillip Morris and disappeared. 
in the Japanese market. They further believed that for adapting to Japan's traditional multi-level distribution channels, they could outsource their sales operations. In fact, they had experienced success using this method experienced with their Bireley's orange juice business. However, their 1960 entry into the instant coffee business did not proceed as hoped. GFC managed to gain only a small portion of the rapidly growing instant coffee market. While their major competitor Nestlé quickly established a dominant market position, GFC had to content itself with distant second position.

Second, GFC's major competitor Nestlé in Japan was, which strengthened ties with traditional distribution channels as well as promoting sales of their product directly to retail outlets. Based on this distribution strategy, Nestlé clearly putting GFC in a weaker position. In response, GFC attempted to internalize sales activities, working on their distribution channels. Thus, GFC's Japanese subsidiary GFL became a fully integrated enterprise with marketing, production and sales functions. But GFC had difficulty finding the right person to direct the management of GFL from within its own organization. As a workaround, GFC scouted an expatriate with a good record in sales working with an American food company in Hong Kong, and appointed him president of their Japanese subsidiary.

Third, under this new regime, GFL offered significant discounts on Maxwell to wholesalers and offered promotional packs of increased volume jars frequently to retail outlets. This sales strategy seemed workable temporalily. In the rapidly expanding instant coffee market, GFL managed to extend sales and to improve its market share. At the same time, however, intermediate inventory built up in the distribution network, and Maxwell came to be used as a cut-price goods in retail stores. It became a loss leader of instant coffee market. Maxwell brand value went into collaps.

Fourth, in the face of these lackluster results, GFC decided on a partial withdrawal from Japan. In 1973, half of the shares of its Japanese subsidiary were transferred to its Japanese major food manufacturer Ajinomoto. In the new company, Ajinomoto General Foods, the Japanese partner provided marketing, production, sales and personnel and labor management, while GFC's contribution to the joint venture was limited to technical aspects alone. GFC was now interested in 
acquiring dividend and licensing fee of technology. On this occasion GFC was substantially set back from Japanese instant coffee business while the Japan's market was proceeding on the growth stage.

Fifth, it has been commonly believed that Japan has been closed economy. However we analyzed that the major reason why GFC's instant coffee business in Japan followed a course contrary to initial expectations was found whitin themselves. It was not able to compete against major competitor Nestlé from Europe. GFC was lack of management personnel for materializing their advantages of technology and product management, for Japanese operations. The GFC's unsuccessful outcome of Japanese operation was caused by underdevelopment of managerial talent for international business. In the reality overseas postings were considered as a career dead-end in GFC. This was affected by the immaturity of global perspective of the top management of GFC. It is considered that they defined their company as a domestic firm with foreign operations. 